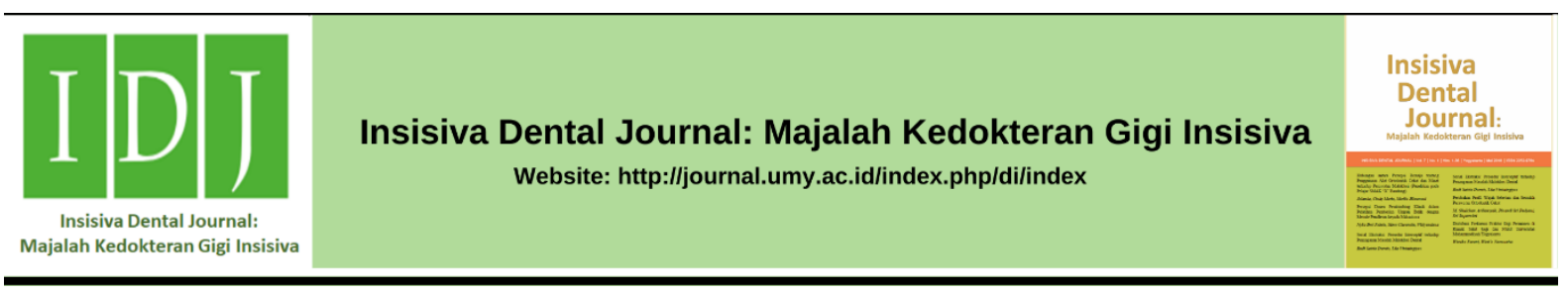

Literature Review

\title{
Perawatan Brown Tumor pada Mandibula Pasien dengan Hiperparatiroid (HPT) Tersier
}

\author{
Treatment of Mandible Brown Tumor in Patients with Tertiary Hyperparathyroidism (HPT)
}

\author{
Agatha Tunggadewi P*, Arsa Hadiyatama Waskitoaji, Wisnu Riyadi, Bambang Tri Hartomo \\ Jurusan Kedokteran Gigi, Fakultas Kedokteran, Universitas Jenderal Soedirman, Jl. Dr. Soeparno, Karangwangkal, Grendeng, Kecamatan \\ Purwokerto Utara, Kabupaten Banyumas, Jawa Tengah 53122, Indonesia. \\ Rumah Sakit Gigi dan Mulut Universitas Jenderal Soedirman, Jl. Dr. Soeparno, Karangwangkal, Grendeng, Kecamatan Purwokerto Utara, \\ Kabupaten Banyumas, Jawa Tengah 53122, Indonesia.
}

Received date: Received date July $9^{\text {th }}, 2020$; revised date October $18^{\text {th }}, 2021$; accepted November $11^{\text {st }}, 2021$ DOI : 10.18196/di.v10i1.9301

\begin{abstract}
Abstrak
Hiperparatiroidisme (HPT) merupakan kondisi yang disebabkan oleh meningkatnya produksi dan sekresi hormon paratiroid (PTH). Tipe HPT diklasifikasikan menjadi tiga dan HPT tersier merupakan yang paling jarang terjadi. Kerusakan tulang merupakan komplikasi yang paling sering terjadi pada HPT tersier yaitu sebesar $25 \%$ dari total pasien HPT dan brown tumor merupakan salah satu bagian dari komplikasi tersebut. Lesi ini sering terjadi pada tulang kortikal, termasuk mandibula. Pemeriksaan klinis, radiografis, histopatologi, dan biokimia serum dilakukan dalam upaya diagnosis brown tumor. Perawatan brown tumor dilakukan melalui dua pendekatan yaitu bedah dan non-bedah. Tujuan dari penulisan telaah pustaka ini adalah menjelaskan pentingnya diagnosis dan perawatan yang tepat pada kondisi brown tumor pada mandibula oleh dokter gigi sehingga kerusakan yang lebih parah dapat dicegah. Pemilihan jenis perawatan lesi brown tumor yang tepat didapatkan melalui pemeriksaan yang komprehensif sehingga didapatkan hasil perawatan yang memuaskan. Telaah pustaka ini berjenis telaah pustaka naratif. Pencarian pustaka dilakukan melalui sumber elektronik seperti PubMed, Google Scholar, dan Clinical Key dengan kriteria inklusi dan eksklusi tertentu. Kesimpulan dari telaah pustaka ini adalah pemeriksaan klinis, laboratoris, histologis, serta radiografis yang baik menghasilkan diagnosis yang tepat sehingga dapat mencegah keparahan dan mengurangi kerusakan akibat lesi tersebut.
\end{abstract}

Kata Kunci: Brown Tumor; Enukleasi; Hiperparatiroid; Hormon Paratiroid; Paratiroidektomi.

\begin{abstract}
Hyperparathyroidism (HPT) is caused by the increased production and secretion of parathyroid hormone (PTH). HPT is classified into three, and tertiary HPT is the least common. Bone damage is the most common complication in tertiary HPT, which is $25 \%$ of the total HPT patients and brown tumor is one of these complications. These lesions manifest in cortical bone, including the mandible. Clinical, radiographic, histopathological, and serum biochemical examinations were performed to diagnose brown tumors. Brown tumor treatment is carried out through two approaches, surgical and non-surgical methods. The purpose of this literature review is to explain the importance of proper diagnosis and treatment of brown tumors in the mandible so that further damage can be prevented. The type of treatment for brown tumors is selected through a comprehensive examination to obtain satisfactory treatment results. This literature review was conducted through electronic sources such as PubMed, Google Scholar, and Clinical Key with certain inclusion and exclusion criteria. Based on the result of this study, it can be concluded that good clinical, laboratory, histological, and radiographic examination of brown tumors will result in the right diagnosis so that further damage can be prevented and reduced.
\end{abstract}

Keywords: Brown Tumor, Enucleation, Hyperparathyroidism, Parathyroid Hormone, Parathyroidectomy.

\footnotetext{
* Corresponding author, e-mail: agathatunggadewi@gmail.com
} 


\section{PENDAHULUAN}

Hormon paratiroid (PTH) diproduksi serta disekresi oleh kelenjar paratiroid dan aktivitasnya diregulasi oleh kadar kalsium bebas pada serum. ${ }^{1}$ Kadar PTH dapat meningkat oleh berbagai penyebab antara lain defisiensi vitamin $\mathrm{D}$, gagal ginjal kronis, dan kondisi keganasan. $\stackrel{2}{2}$ Kondisi kadar PTH yang meningkat dinamakan hiperparatiroidisme. Hiperparatiroidisme (HPT) berdasarkan etiologinya terbagi menjadi tiga jenis, yaitu HPT primer, HPT sekunder, dan HPT tersier. HPT primer ditandai dengan peningkatan kadar PTH oleh karena abnormalitas dari salah satu atau kedua kelenjar paratiroid. $\stackrel{2}{ }$ HPT sekunder utamanya disebabkan oleh kerusakan ginjal kronis sehingga terjadi gangguan homeostasis kalsium dan vitamin D pada serum sementara HPT tersier merupakan kelanjutan dari kondisi HPT sekunder. - $^{-}$ Hiperparatiroidisme (HPT) tersier ditandai dengan aktivitas otonom kelenjar paratiroid dalam mensekresi hormon paratiroid (PTH). ${ }^{4}$ Kondisi pada HPT tersier ini umumnya timbul akibat kegagalan fungsi ginjal dan menetap meskipun fungsi ginjal sudah kembali melalui transplantasi ginjal. ${ }^{5}$ Hiperparatiroidisme pada umumnya ditandai dengan dekalsifikasi tulang (10$20 \%$ total pasien HPT) dan terbentuknya batu ginjal (10-25\% total pasien HPT). ${ }^{6}$

Kadar PTH yang meningkat dapat memengaruhi keseimbangan aktivitas osteoblas dan osteoklas..$^{\frac{5}{}}$ Keseimbangan aktivitas osteoblas dan osteoklas yang terganggu menyebabkan peningkatan aktivitas destruksi tulang. Kondisi ini menjadi penyebab tingginya komplikasi berupa kerusakan tulang yaitu sebesar $25 \%$ dari total pasien HPT. Manifestasi klinis dari kerusakan tulang tersebut dapat berupa osteoporosis yang terjadi secara menyeluruh, demineralisasi tulang yang progresif, central giant cell granuloma, dan terbentuknya kista osteitis fibrosa (brown tumor). 1

Brown tumor (BT) atau osteitis fibrosa cystica merupakan lesi yang disebabkan oleh adanya aktivitas sel raksasa berlebih pada tulang. Lesi ini ditandai dengan tingginya resorpsi tulang yang terlokalisir dan selanjutnya akan terisi dengan jaringan fibrous. ${ }^{7}$ Prevalensi terjadinya lesi ini adalah sebesar $0,1 \%$ dari total pasien hiperparatiroidisme. ${ }^{8}$ Diagnosis brown tumor didapatkan melalui berbagai pemeriksaan yaitu pemeriksaan klinis, laboratoris, histologis, dan radiologis. Hasil dari berbagai pemeriksaan inilah yang dapat membedakan lesi brown tumor dengan lesi lainnya seperti central giant cell granuloma (CGCG) dan ameloblastoma. $, \underline{9}, \underline{10}, \underline{11}, \underline{12}$

Brown tumor pada rongga mulut muncul sebagai lesi eksofilik disertai rasa nyeri, berekspansi secara lambat, memiliki konsistensi yang keras, dan tidak bergerak saat dipalpasi. Lesi ini bersifat ekspansif, destruktif, dan dapat menyebabkan gangguan pengunyahan, pernafasan, dan sensori pada regio maksilofasial. Hal tersebut menjadi alasan pentingnya diagnosis dan pemilihan perawatan yang tepat sehingga dapat meningkatkan keberhasilan perawatan dan mencegah kerusakan yang lebih parah akibat lesi ini. Berbagai literatur menyebutkan keberhasilan perawatan brown tumor baik melalui pendekatan non-bedah, bedah, maupun keduanya. Jenis perawatan tersebut dipilih dengan mempertimbangkan berbagai aspek seperti usia pasien, perluasan lesi, lokasi lesi, dan keparahan kondisi hiperparatiroid pada masingmasing pasien. $1, \underline{3}, 8,13,14,15,16,17$

Tujuan dari penulisan telaah pustaka ini adalah untuk membahas pentingnya diagnosis dan pemilihan perawatan yang tepat pada kondisi brown tumor mandibula oleh dokter gigi sehingga dapat meningkatkan keberhasilan perawatan dan mencegah kerusakan yang lebih parah akibat lesi brown tumor.

\section{MATERIAL DAN METODE}

Telaah pustaka merupakan jenis telaah pustaka naratif atau tradisional. Pencarian pustaka dilakukan secara 
komprehensif dan sistematik melalui sumber (database) elektronik seperti PubMed, Google Scholar, dan Ebscohost. Pencarian literatur melalui sumber data tersebut dilakukan menggunakan beberapa kata kunci seperti "brown tumour", "brown tumors", "tumor coklat", "osteitis fibrosa cystica", "mandibula", "mandible", "destruksi mandibula", "hyperparathyroidism", "hiperparatiroid", "hiperparatiroid tersier", "adenoma", "paratiroidektomi”, "enukleasi”, "kuretase", dan "penyembuhan luka".

Kriteria inklusi dari literatur yang digunakan sebagai sumber pada artikel review ini di antaranya adalah (1) laporan kasus brown tumor pada regio mandibular pada pasien dengan hiperparatiroidisme tersier, (2) literature diterbitkan antara tahun 2012 hingga 2021, (3) literatur diterbitkan dalam Bahasa Indonesia atau Bahasa Inggris, (4) literatur tersedia dalam versi lengkap, dan (5) literatur memuat hasil pemeriksaan, jenis perawatan, dan hasil perawatan pada kasus secara lengkap. Kriteria eksklusi dari literatur yang digunakan pada artikel review ini di antaranya adalah (1) literatur dalam bentuk artikel penelitian, (2) lesi brown tumor tidak terjadi pada regio maksilofasial, (3) tidak adanya kondisi hiperparatiroid pada pasien, (4) informasi yang tidak lengkap dari pasien (umur, jenis kelamin, jenis hiperparatiorid, lokasi lesi, dan keterangan pemeriksaan dari pasien baik pemeriksaan klinis, laboratoris, histologis, maupun radiografis), serta (5) adanya penyakit lain pada pasien yang dapat memengaruhi keparahan lesi pada rongga mulut.

\section{HASIL}

Hormon paratiroid (PTH) diproduksi dan disekresi oleh kelenjar paratiroid. PTH bersama dengan vitamin D3 (1.25-dihydroxycholecalciferol) dan kalsitonin berperan dalam mengatur kadar kalsium dan fosfat dalam serum. ${ }^{13}$ Mekanisme peningkatan kadar kalsium dalam serum ini adalah dengan meningkatkan pelepasan kalsium dan fosfat dari matriks tulang, meningkatkan reabsorpsi kalsium pada tubulus ginjal, meningkatkan absorpsi kalsium pada usus halus, serta menurunkan reabsorpsi fosfat. $\underline{18}$ Pelepasan kalsium dan fosfat terjadi karena adanya ikatan PTH dengan osteoblas pada tulang, kemudian menstimulasi produksi receptor activator of nuclear factor kappa$B$ ligand (RANKL) serta menurunkan aktivitas osteoprotegerin. RANKL akan menstimulasi maturasi dan aktivitas resorpsi oleh osteoklas sehingga terjadi pelepasan kalsium pada pada tulang. $\frac{5}{}$ Mekanisme peningkatan kadar kalsium plasma ini dapat dilihat pada Gambar 1.

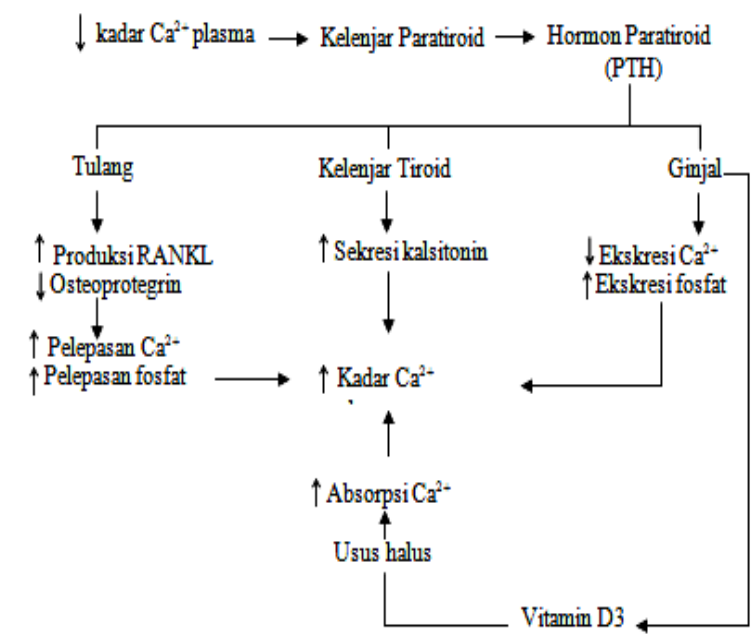

Gambar 1. Mekanisme peningkatan kadar kalsium plasma oleh PTH

Hiperparatiroid merupakan kondisi yang disebabkan oleh produksi dan sekresi hormon paratiroid (PTH) yang berlebih. ${ }^{13}$ Hiperparatiroid ditandai dengan dekalsifikasi tulang (10-20\% total pasien HPT) dan terbentuknya batu ginjal yang mengandung kalsium (10-25\% total pasien HPT).$\underline{6}$ Hiperparatiroid berdasarkan etiologinya terbagi menjadi hiperparatiroid primer, sekunder, dan tersier. Hiperparatiroid (HPT) primer ditandai dengan peningkatan sekresi PTH oleh karena abnormalitas dari salah satu atau lebih kelenjar paratiroid. Adenoma merupakan salah satu jenis abnormalitas yang paling sering terjadi yaitu sebesar $85 \%$ dari total kasus HPT primer. HPT primer pada pemeriksaan darah rutin 
menunjukkan tanda hiperkalsemia dan hipofosfataemia. ${ }^{\underline{2}}$

Hiperparatiroid (HPT) sekunder merupakan salah satu komplikasi pada gagal ginjal kronik. $\frac{19}{}$ Penyakit ini disebabkan oleh ketidakmampuan ginjal dalam memetabolisme vitamin D3 sehingga terjadi gangguan ekskresi fosfat yang menyebabkan kadar fosfat meningkat dalam darah (hiperfosfatemia), menurunnya absorpsi kalsium, dan defisiensi vitamin D3. $\frac{20}{}$ Menurunnya absorpsi kalsium pada usus halus dan defisiensi vitamin D3 menyebabkan hipokalsemia kronis. Kondisi tersebut menyebabkan kelenjar paratiroid bekerja lebih keras dalam memproduksi PTH dan mengalami hyperplasia. $\frac{1}{}$ Hiperparatiroid (HPT) tersier merupakan penyakit yang timbul akibat HPT sekunder yang berkepanjangan dan $30 \%$ dari total kasus terjadi pada pasien dengan transplantasi ginjal. Penyakit ini ditandai dengan aktivitas otonom kelenjar paratiroid dalam mensekresi hormon paratiroid (PTH). ${ }^{4}$ Kadar PTH terus meningkat pada kondisi ini meskipun fungsi ginjal pasien sudah kembali. Peningkatan kadar PTH tersebut disebabkan karena kelenjar paratiroid yang sudah mengalami hiperplasia gagal untuk melakukan penyembuhan. HPT tersier ditandai dengan peningkatan kadar alkalin fosfatase dan PTH. ${ }^{9}$ Kondisi hiperparatiroid (HPT) dapat menimbulkan berbagai komplikasi salah satuya gangguan muskuloskeletal. Gangguan muskuloskeletal muncul karena ketidakseimbangan aktivitas osteoblas dan osteoklas akibat aktivitas PTH. Beberapa penyakit muskuloskeletal yang dapat timbul adalah osteoporosis, central giant cell granuloma, dan brown tumor. $\underline{14}$

\section{Brown Tumor}

Brown tumor (osteitis fibrosa cystica) merupakan lesi non-neoplastik yang terbentuk akibat abnormalitas metabolisme tulang pada pasien hiperparatiroid (HPT)..,$\underline{3,10,13}$ Brown tumor ditemukan pada $3 \%$ kasus HPT primer dan 1,5-1,7\% kasus HPT sekunder dan tersier. Lesi ini muncul akibat peningkatan hormon paratiroid (PTH) yang menyebabkan peningkatan aktivitas resorpsi oleh osteoklas secara lokal, utamanya pada tulang kortikal. $\stackrel{21}{ }$ Berbagai laporan kasus menyebutkan rata-rata usia pasien hiperparatiroidisme dengan lesi brown tumor adalah 41 tahun (rentang usia antara 19 hingga 68 tahun) dengan 68\% kasus terjadi pada wanita., $, \underline{30}, \underline{13}, \underline{16}$ Diagnosis brown tumor ditegakkan melalui berbagai macam pemeriksaan yaitu pemeriksaan klinis, pemeriksaan histopatologi, pemeriksaan laboratorium, dan pemeriksaan radiologi. $\underline{10}$

Lesi brown tumor pada rongga mulut umumnya berkembang pada mandibula sebagai manifestasi tunggal selain itu lesi ini juga dapat berkembang pada maksila sehingga terbentuk manifestasi multipel.. , $\underline{14}, \underline{16}$ Beberapa tanda lesi brown tumor pada rongga mulut di antaranya pembengkakan baik tunggal maupun multipel (91\% kasus), rasa nyeri (36,3\% kasus), kegoyangan dan tanggalnya gigi (31,8\% kasus), dan jaringan lunak di sekitar lesi mudah berdarah (13,6\% kasus). Berbagai tanda lesi brown tumor pada rongga mulut di antaranya adalah pembengkakan yang meluas ke jaringan di sekitarnya (100\% kasus), rasa nyeri $(36,3 \%$ kasus), kegoyangan dan tanggalnya gigi (31,8\% kasus), jaringan lunak di sekitar lesi mudah berdarah $(13,6 \%$ kasus $)$, serta keterbatasan membuka mulut $(13,6 \%$ lasis)., $, 10,13,14$ Pembengkakan oleh lesi brown tumor berisi masa berwarna merah kecoklatan yang rapuh. Warna merah kecoklatan ini berasal dari vaskularitas yang ada di dalam lesi, hemoragi, dan deposit hemosiderin. Warna merah 
kecoklatan ini mendasari mengapa lesi ini disebut dengan brown tumor atau tumor coklat. $18, \underline{22,23,24}$ Manifestasi oral brown tumor dapat dilihat pada Gambar 2.

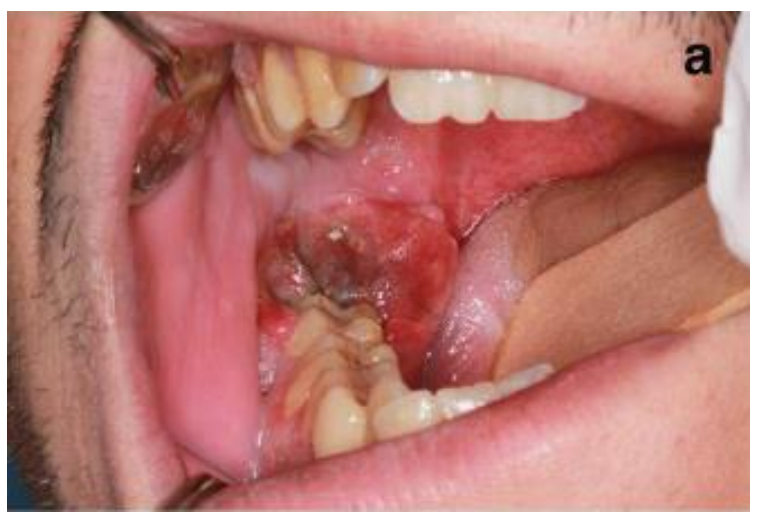

Gambar 2. Manifestasi Oral Lesi Brown Tumor ${ }^{15}$

Brown tumor dalam gambaran histopatologi tampak sebagai massa jaringan lunak yang terdiri atas kumpulan sel raksasa multinukleat yang menyerupai osteoklas pada stroma fibrovaskular. Masa ini terletak pada rongga menyerupai lesi kista yang dikelilingi oleh jaringan ikat, dan hemoragi pada pusat lesi yang disebabkan oleh mikrofraktur sehingga terjadi pelepasan hemosiderin. , $, 9,25_{\text {Gambaran }}$ histologi brown tumor dapat dilihat pada Gambar 3.

Pemeriksaan laboratoris diperlukan dalam menentukan diagnosis brown tumor. Pemeriksaan klinis brown tumor dikaitkan dengan kondisi hiperparatiroid. $\underline{26}$ Pasien dengan kondisi hiperparatiroid tersier pada umumnya menunjukkan kadar kalsium yang meningkat atau normal (normal: 8,410,2 $\mathrm{mg} / \mathrm{dl}$ ), peningkatan kadar PTH (normal: $10-65 \mathrm{pg} / \mathrm{ml}$ ), penurunan kadar vitamin $\mathrm{D}$ dan fosfat (normal: 2,5-4,5 $\mathrm{mg} / \mathrm{dl}$ ), dan peningkatan kadar alkalin fosfatase (normal: 440147 IU/L). $, 9,9,10,13$

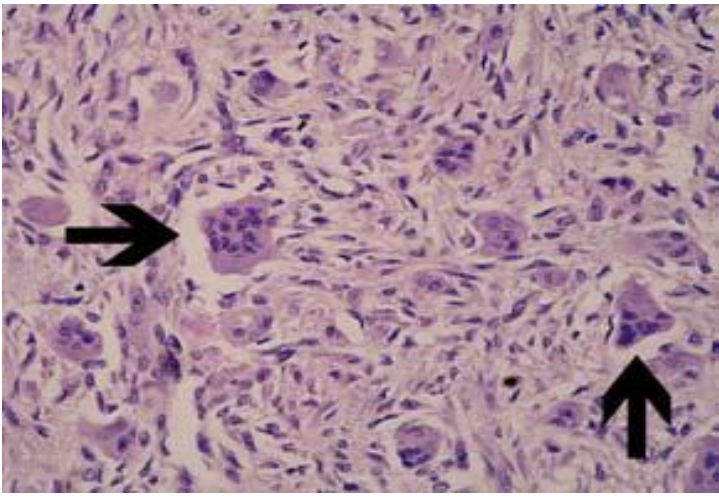

Gambar 3. Gambaran histology brown tumor menunjukkan kumpulan sel raksasa berinti banyak. ${ }^{9}$

Pemeriksaan radiologi pada brown tumor umumnya dilakukan menggunakan orthopantomogram (OPG). Pemeriksaan ini dilakukan untuk mengetahui letak, tepi, ukuran, jumlah lesi, dan keterlibatan struktur sekitar. $\stackrel{14}{ }$ Gambaran radiografis brown tumor pada beberapa literatur laporan kasus menunjukkan adanya lesi osteolitik monolokular (25\% kasus) atau multilokular (75\% kasus) dengan batas jelas. Brown tumor yang terletak pada mandibula pada umumnya mengakibatkan penurunan densitas tulang rahang (59\% kasus), ekspansi dan penipisan tulang kortikal (54,4\% kasus), hilangnya lamina dura pada gigi di sekitar lesi (41\% kasus), dan adanya gambaran salt and pepper atau ground-glass $(22,7 \%$ kasus)., $, 3, \underline{10}, \underline{13}, \underline{21}, \underline{24}, \underline{27}$ Lesi brown tumor juga sering kali menyebabkan resorpsi pada akar gigi di regio sekitar lesi sehingga menciptakan gambaran floating teeth $(36,3 \%$ kasus).,,$\underline{10,14,28}$ Gambaran radiografi brown tumor dapat dilihat pada Gambar 4.

\section{Diagnosis banding Brown Tumor}

Brown tumor sering dikaitkan dengan beberapa lesi tulang lainnya terkait dengan etiologi dan gambaran klinis serta radiografisnya. Dua lesi yang sering dikaitkan dengan brown tumor adalah central giant cell granuloma (CGCG) dan ameloblastoma. $\underline{10}^{\underline{13}}$ 
Central giant cell granuloma (CGCG) merupakan lesi non-neopalastik yang hanya terjadi pada $7 \%$ kasus lesi benigna pada rahang. Lesi CGCG dan brown tumor memberikan gambaran radiografis berupa lesi multiokular dengan erosi bagian apikal gigi di sekitar lesi. Hal ini menyebabkan CGCG menjadi salah satu lesi yang sering dikaitkan dengan brown tumor.,$\underline{9,13}$ Kadar PTH umumnya mengalami peningkatan yang lebih tinggi pada kondisi CGCG di bandingkan dengan brown tumor. ${ }^{12}$ Selain itu, riwayat medis pasien juga diperlukan untuk mengetahui jenis hiperparatorid (HPT) yang diderita pasien tersebut. Lesi CGCG pada umumnya timbul pada kondisi HPT primer sedangkan brown tumor dapat timbul pada ketiga jenis hiperparatiroid (HPT)..$\underline{10}$

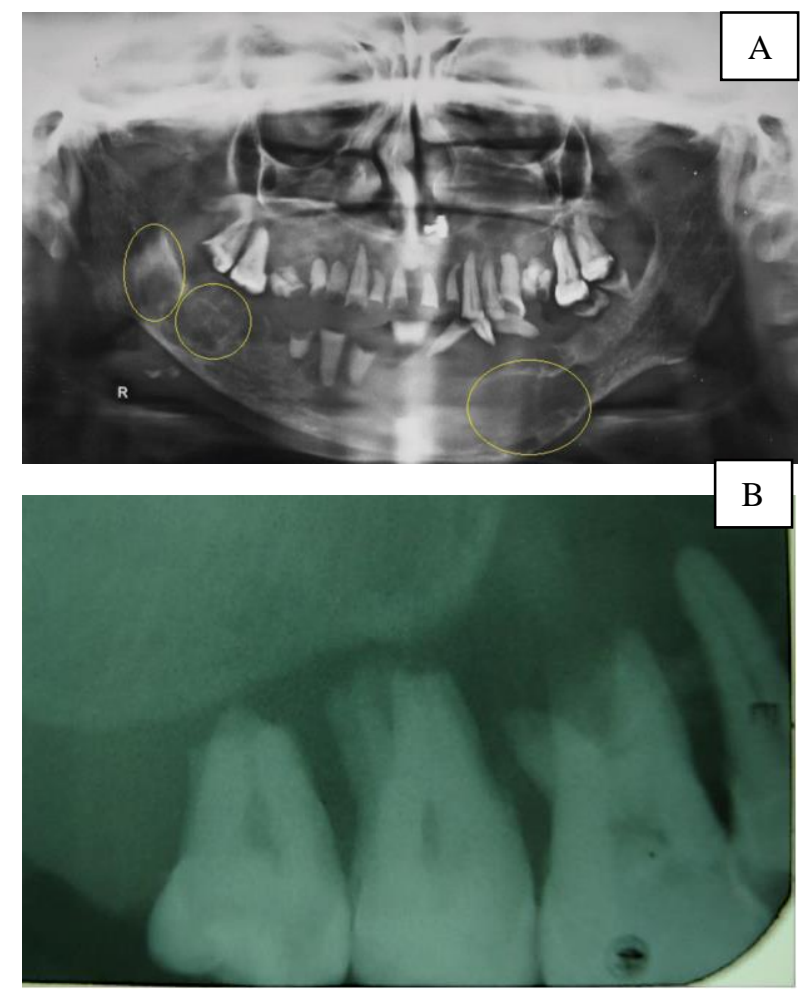

Gambar 4. Radiografi panoramic lesi brown tumor menunjukkan gambaran radiolusensi multilokular yang berekspansi (A) serta hilangnya lamina dura dan resorpsi akar pada gigi di sekitar lesi sehingga menciptakan gambaran floating teeth $(\mathrm{B})^{28,29}$

Ameloblastoma juga menjadi salah satu diagnosis banding dari brown tumor. Kedua lesi ini pada umumnya terletak pada ramus dan korpus mandibula serta timbul pada pasien $30-50$ tahun. $\frac{10}{}$ Pemeriksaan laboratorium dan radiografi dibutuhkan untuk membedakan antara kedua lesi ini. Ameloblastoma merupakan kista odontogenik sehingga pada gambaran radiografinya menunjukkan adanya keterlibatan struktur gigi, selain itu pada ameloblastoma tidak menunjukkan adaya abnormalitas kadar PTH, kalsium, dan fosfat pada pemeriksaan laboratories. ${ }^{11}$ Perbedaan antara brown tumor, CGCG, dan ameloblastoma dapat dilihat pada Tabel 1 .

\section{Penatalaksanaan Brown Tumor}

Brown tumor merupakan lesi ekspansif yang dapat terjadi pada tulang kraniofasial. Meskipun tingkat kejadian brown tumor tergolong rendah namun lesi ini perlu menjadi perhatian karena sifatnya yang ekspansif dan destruktif sehingga rentan menimbulkan deformitas pada struktur terkait. $\underline{13}, \underline{25}, \underline{30}$ Brown tumor pada rongga mulut dapat menyebabkan deformitas pada wajah, dislokasi gigi, dan ekspansi pada tulang kortikal sehingga tulang menjadi lebih tipis. $\underline{13}, \underline{16}, \underline{18}, \underline{22}, \underline{27}$ Kondisi tersebut menjadi alasan mengapa diagnosis dini dan perawatan yang tepat sangat diperlukan untuk mengurangi parahnya kerusakan akibat lesi. $\underline{10, \underline{30}}$

Perawatan brown tumor dapat dilakukan melalui berbagai pendekatan, baik secara bedah maupun non-bedah bergantung pada tingkat keparahan penyakit ini. $\frac{18}{}$ Noleto (2020) menyatakan perawatan pada brown tumor juga harus mempertimbangkan kondisi hiperparatiroid (HPT) pasien sebagai penyebab timbulnya lesi. Berbagai penelitian menyatakan pentingnya kontrol kadar PTH sebagai salah satu strategi perawatan brown tumor pada HPT tersier. Salah satu perawatan yang dapat dilakukan adalah melalui prosedur paratiroidektomi. $\underline{13}, \underline{14}, \underline{15}, \underline{22}$ 
Paratiroidektomi dianjurkan menjadi perawatan utama dengan tujuan menghilangkan kondisi HPT sebagai penyebab terjadinya brown tumor. Paratiroidektomi diindikasikan bagi kelenjar paratiroid yang mengalami hyperplasia serta menimbulkan lesi yang ekspansif, menimbulkan rasa sakit, dan

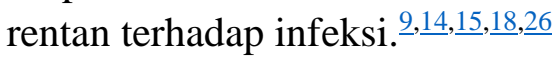

Tabel 1. Perbedaan antara brown tumor, CGCG, dan ameloblastoma

\begin{tabular}{|c|c|c|c|}
\hline & Brown tumor & CGCG & Ameloblastoma \\
\hline $\begin{array}{l}\text { Gambaran } \\
\text { Klinis }\end{array}$ & $\begin{array}{l}\text { Berupa perbesaran pada } \\
\text { posterior mandibula dengan } \\
\text { konsistensi keras }\end{array}$ & $\begin{array}{l}\text { Berupa perbesaran pada } \\
\text { posterior mandibula dengan } \\
\text { konsistensi keras }\end{array}$ & $\begin{array}{l}\text { Berupa perbesaran pada } \\
\text { mandibula dengan } \\
\text { konsistensi keras }\end{array}$ \\
\hline $\begin{array}{l}\text { Prevalensi } \\
\text { berdasarkan } \\
\text { umur }\end{array}$ & $\begin{array}{l}\text { Dapat terjadi pada semua } \\
\text { rentang umur pasien }\end{array}$ & $\begin{array}{l}\text { Dapat terjadi pada semua } \\
\text { rentang umur pasien }\end{array}$ & $\begin{array}{l}\text { Banyak terjadi pada pasien } \\
\text { berumur 30-50 tahun }\end{array}$ \\
\hline $\begin{array}{l}\text { Gambaran } \\
\text { histopatologi }\end{array}$ & $\begin{array}{l}\text { Tampak sebagai massa } \\
\text { jaringan lunak yang terdiri } \\
\text { atas kumpulan sel raksasa } \\
\text { multinukleat yang menyerupai } \\
\text { osteoklas pada stroma } \\
\text { fibrovaskular, } \\
\text { hemosiderin sehingga bagian } \\
\text { inti lesi berwarna merah } \\
\text { kecoklatan. }\end{array}$ & $\begin{array}{l}\text { Tampak sebagai massa } \\
\text { jaringan lunak yang terdiri } \\
\text { atas kumpulan sel raksasa } \\
\text { multinukleat } \\
\text { menyerupai osteoklas pada } \\
\text { stroma fibrovaskular, tidak } \\
\text { selalu disertai dengan } \\
\text { deposit hemosiderin pada } \\
\text { inti lesi. }\end{array}$ & $\begin{array}{l}\text { Terdapat gambaran sel } \\
\text { epitel odontogenik yang } \\
\text { mengalami proliferasi, sel } \\
\text { tumor berbagai bentuk } \\
\text { dengan inti hiperkromatik di } \\
\text { basal dan tersusun } \\
\text { palisading pada bagian tepi, } \\
\text { tidak terdapat gangguan } \\
\text { pada aktivitas sel raksasa. }\end{array}$ \\
\hline $\begin{array}{l}\text { Gambaran } \\
\text { radiografi }\end{array}$ & $\begin{array}{l}\text { Lesi osteolitik monolokular } \\
\text { atau multilokular dengan batas } \\
\text { jelas, ekspansi dan penipisan } \\
\text { tulang kortikal, resorpsi akar } \\
\text { dan hilangnya lamina dura } \\
\text { gigi di sekitar lesi, serta } \\
\text { terdapat gambaran "ground- } \\
\text { glass" atau "salt and pepper". }\end{array}$ & $\begin{array}{l}\text { Lesi osteolitik monolokular } \\
\text { atau multilokular dengan } \\
\text { batas jelas, ekspansi dan } \\
\text { penipisan tulang kortikal, } \\
\text { resorpsi akar dan hilangnya } \\
\text { lamina dura dan pergeseran } \\
\text { gigi, serta gambaran "wispy } \\
\text { septation" atau septa tipis di } \\
\text { dalam lesi. }\end{array}$ & $\begin{array}{l}\text { Lesi ekspansil dengan } \\
\text { penipsan korteks pada } \\
\text { buccal dan lingual plane, } \\
\text { terdapat keterlibatan gigi } \\
\text { yang menimbulkan lesi, } \\
\text { akar gigi yang terlibat } \\
\text { terlihat menumpul, serta } \\
\text { terdapat gambaran "soap } \\
\text { bubble" atau "honey comb" }\end{array}$ \\
\hline
\end{tabular}

Prosedur paratiroidektomi dapat membantu mengontrol kadar PTH dan menghambat pelepasan kalsium dan fosfat pada tulang sehingga terjadi peningkatan densitas tulang pada lesi. Hal ini didukung oleh Can dkk. dan Torres dkk. pada penelitiannya yang menyatakan bahwa kontrol kadar PTH dapat membantu mengurangi keparahan bahkan terjadi penyembuhan spontan lesi brown tumor.,$\underline{18,26,31}$ Berbagai kasus menunjukkan keberhasilan perawatan brown tumor hanya dengan manajemen kadar PTH melalui prosedur paratiroidektomi. Lesi brown tumor terlihat mengecil dan mengalami penyembuhan tanpa adanya komplikasi dan kekambuhan pada beberapa kasus pasien tersebut $(36,3 \%$ kasus). $., 7, \underline{8}, \underline{13}, 14,15$

Kontrol kadar PTH dalam rangka perawatan brown tumor juga dapat dilakukan dengan pemberian medikasi berupa kalsitonin dosis $100 \mathrm{IU} / \mathrm{ml}$ dan kortikosteroid dosis $20 \mathrm{mg} / \mathrm{ml}$ yang diinjeksikan ke dalam lesi. Kalsitonin berperan dalam menghambat resorpsi 
tulang dengan menghambat aktivitas mediator lokal yang mengontrol metabolisme kalsium sedangkan kortikosteroid intralesi bekerja dengan menghambat aktivitas sel raksasa pada lesi. ${ }^{3,8,21}$ Perawatan ini direkomendasikan menjadi perawatan utama karena sederhana, murah, dan tidak invasif sehingga struktur yang terlibat dapat dipertahankan. $\underline{18}$ Hemodialisis dan transplantasi ginjal juga dapat menjadi pilihan perawatan brown tumor dengan tujuan mengembalikan fungsi ginjal. Kedua perawatan ini bertujuan untuk menormalkan kadar PTH dalam serum. ${ }^{18,23}$

Beberapa literatur laporan kasus pasien menunjukkan tidak optimalnya perawatan lesi brown tumor yang hanya dilakukan melalui prosedur manajemen kadar PTH pada tubuh. Beberapa kasus pasien tersebut menunjukkan kegagalan perawatan brown tumor yang ditandai dengan pembengkakan yang semakin parah dan munculnya pembengkakan pada regio ekstraoral yang disertai dengan gangguan sistemik seperti rasa lelah dan nyeri pada tubuh. Hal ini menjadi alasan perlunya perawatan brown tumor yang dilakukan secara lokal melalui tindakan bedah.,, 9

Tindakan bedah berupa kuretase dan enukleasi dapat dilakukan dalam perawatan brown tumor. $, \underline{10}, \underline{13}, \underline{21}$ Perawatan ini menjadi pilihan perawatan utama jika lesi brown tumor tidak mengalami penyembuhan setelah perawatan nonbedah, berkembang secara progresif, menimbulkan deformitas pada wajah, dan pasien menginginkan penyembuhan yang lebih cepat.,$\underline{96, \underline{1}}$ Enukleasi dan kuretase merupakan tindakan bedah yang sering dilakukan dalam perawatan brown tumor. $-\underline{6,10,21}$

Enukleasi merupakan pengangkatan lesi baik dari lapisan pembungkus maupun isinya sementara kuretase merupakan pemisahan lesi dari jaringan sekitar dengan pemotongan. Enukleasi diindikasikan pada lesi yang ekspansif dan tingkat rekurensinya tinggi sementara kuretase diindikasikan pada lesi yang kecil dan tidak ekspansif. 10,32 Tindakan bedah berupa enuklasi atau kuretase memberikan hasil yang baik pada perawatan brown tumor di mana lesi mengalami penyembuhan setelah dilakukannya normalisasi kadar PTH dan perawatan bedah $(36,3 \%$ kasus $) ., 9,10,16,21$

\section{KESIMPULAN}

Brown tumor pada mandibular merupakan salah satu komplikasi yang dapat terjadi pada pasien dengan kondisi hiperparatiroidisme tersier di mana lesi ini bersifat ekspansif, destruktif, dan dapat menyebabkan gangguan sensori pada regio maksilofasial. Pemeriksaan klinis, laboratoris, histologis, serta radiografis yang baik menghasilkan diagnosis yang tepat sehingga perawatan lesi brown tumor dapat dilakukan secara tepat. Jenis perawatan lesi brown tumor dipilih berdasarkan kondisi sistemik pasien serta keparahan dan perluasan dari lesi sehingga pemilihan jenis perawatan yang tepat dapat mencegah keparahan dan mengurangi kerusakan akibat lesi tersebut.

\section{DAFTAR PUSTAKA}

1. Nunes TB, Bologna SB, Witzel AL, Nico MMS, Lourenço SV. A Rare Case of Concomitant Maxilla and Mandible Brown Tumours, Papillary Thyroid Carcinoma, Parathyroid Adenoma, and Osteitis Fibrosa Cystica, Case Reports in Dentistry. 2016.

\section{https://doi.org/10.1155/2016/5320298}

2. Choi JH, Kim KJ, Lee YJ, Kim SH, Kim SG, Jung KY, et al. Primary hyperparathyroidism with extensive brown tumors and multiple fractures in a 20-year-old woman, Endocrinology and Metabolism. 2015;30(4):614-619. 
https://doi.org/10.3803/EnM.2015.30. 4.614

3. Singhal A, Chandra B, Seth S. Unusually Large Brown tumor of Mandible in a Case of Secondary Hyperparathyroidism Mimicking Cherubism, Indian Journal of Nuclear Medicine. 2019;33(2):359-362.

4. Talukder S, Behera A, Bhadada SK, Mitra S. Giant mediastinal parathyroid adenoma presenting as bilateral brown tumour of mandible: A rare presentation of primary hyperparathyroidism, British Medical Journal,2017;1-5.

https://doi.org/10.1136/bcr-2017$\underline{220722}$

5. Palla B, Burian E, Fliefel R, Otto S. Systematic review of oral manifestations related to hyperparathyroidism, Clinical Oral Investigation.2018;22(1):1-28. https://doi.org/10.1007/s00784-0172124-0

6. Brabyn P, Capote A, Belloti M, Zylberberg I. Hyperparathyroidism Diagnosed Due to Brown Tumors of the Jaw: A Case Report and Literature Review, Journal of Oral and Maxillofacial Surgery. 2017;75(10):2162-9. https://doi.org/10.1016/j.joms.2017.03 $\underline{.013}$

7. Jafari-Pozve N, Ataie-Khorasgani M, Jafari-Pozve N, Ataie-Khorasgani M, Ataie-Khorasgani M, Jafari-Pozve S. Maxillofacial brown tumors in secondary hyperparathyroidism: A case report and literature review. J Res Med Sci. 2014;19(11):1099-102.

8. Zou H, Song L, Jia M, Wang L, Sun Y. Brown tumor of multiple facial bones associated with primary hyperparathyroidism: A clinical case report., Medicine. 2018;97(33):1-4. https://doi.org/10.1097/MD.00000000 $\underline{00011877}$
9. Dorigatti De Ávila É, De Molon RS, Cabrini Gabrielli MA, Hochuli-Vieira E, Sgavioli Massucato EM, De MelloFilho FV, et al. Unusually rapid growth of brown tumour in the mandible after parathyroidectomy associated with the presence of a supernumerary parathyroid gland, Journal of CranioMaxillofacial Surgery, 40(1):e19-23. https://doi.org/10.1016/j.jcms.2011.01 .001

10. Guéroult AM, Cameron M. Rare brown tumour of the mandible secondary to tertiary hyperparathyroidism in a renal transplant recipient, British Medical Journal.2019;12(9):10-13.

https://doi.org/10.1136/bcr-2019231231

11. Effiom OA, Ogundana OM, Akinshipo AO, Akintoye SO. Ameloblastoma: current etiopathological concepts and management, Oral Disease. 2018; 24(3):307-316.

https://doi.org/10.1111/odi.12646

12. Gulati D, Bansal V, Dubey P, Pandey S, Agrawal A. Central giant cell granuloma of posterior maxilla: First expression of primary hyperparathyroidism, Case Report of Endocrinology. 2015. https://doi.org/10.1155/2015/170412

13. Noleto J, Ramos IS, Rocha J, Garcia I. Salvador Roberto, B. A rare case of regression of brown tumors of tertiary hyperparathyroidism after parathyroidectomy and renal transplant: A 5-year follow-up, Annual Maxillofacial Surgery. 2016;6(1):125. 10.4103/2231-0746.186123

14. Baral R, Ojha B, Bajracharya D, Bhattacharyya S, Roy S, Singh S. Brown Tumour of Jaw Bone: A Diagnostic Attribute of Hyperparathyroidism, Journal of Nepal Society of Periodontology and Oral Implantology. 2017;1(2):72-74. 
https://doi.org/10.3126/jnspoi.v1i2.23 $\underline{553}$

15. Yucesoy $T$, Kilic E, Dogruel F, Bayram F, Alkan A, Akcan AC, et al. Spontaneous and Excellent Healing of Bilateral Brown Tumors in Mandible after Endocrinal Therapy and Subtotal Parathyroidectomy: Case Report with 4-Year Follow-Up, Case Report in Dentistry. 2018. https://doi.org/10.1155/2018/8070131

16. Lajolo C, Patini R, Limongelli L. Brown tumors of the oral cavity: presentation of 4 new cases and a systematic literature review. Oral Surgery, Oral Medicine, Oral Pathology, and Oral Radiology. 2020;129(6):575-584.

https://doi.org/10.1016/j.000o.2020.02 .002

17. Selcuk AA. A Guide for Systematic Reviews: PRISMA, Turkish Arch Otorhinolaryngol, 2019;57(1):57-58. https://doi.org/10.5152/tao.2019.4058

18. Bezerra, Pinto, AS. Brown Tumor: A Late Complication of Secondary Hyperparathyroidism, Biomedical Journal of Science and Technology Research, 2018;6(3):5274-5277. https://doi.org/10.26717/BJSTR.2018. $\underline{06.001351}$

19. Cozzolino M, Galassi A, Conte F, Mangano M, Di Lullo L, Bellasi A. Treatment of secondary hyperparathyroidism: The clinical utility of etelcalcetide, Therapeutics and Clinical Risk Management. 2017;13:679-689.

https://doi.org/10.2147/TCRM.S1084 $\underline{90}$

20. Elhafeez SA, Bolignano D, D’Arrigo G, Dounousi E, Tripepi G, Zoccali C. Prevalence and burden of chronic kidney disease among the general population and high-risk groups in Africa: A systematic review, British Medical Journal, 2018;8(1). http://dx.doi.org/10.1136/bmjopen2016-015069

21. Popovik-Monevska D, BozovikDvojakovska S, Popovski V, Benedetti A, Grchev A, Koneski F. 2018, Brown tumour in the mandible and skull osteosclerosis associated with primary hyperparathyroidism - a case report, Open Access Maced Journal of Medical Science, 6(2):406-409. https://doi.org/10.3889/oamjms.2018. $\underline{086}$

22. Sia HK, Hsieh MC, Yang LH, Tu STe. 2012, Maxillary brown tumor as initial presentation of parathyroid adenoma: A case report, Kaohsiung Journal Medical Science. 2012;28(7):400-403. https://doi.org/10.1016/j.kjms.2012.02 .008

23. Wilson JJ, Schwartz HC, Tehrany GM. 2013, Brown tumor of the posterior maxilla as initial manifestation of primary hyperparathyroidism: Case report, Journal of Oral and Maxillofacial Surgery, 71(5):886-890. https://doi.org/10.1016/j.joms.2012.11 .013

24. Altay C, Erdogan N, Eren E, Altay S, Karasu S, Uluç E. 2013, Computed tomography findings of an unusual maxillary sinus mass: Brown tumor due to tertiary Hyperparathyroidism, Journal of Clin Imaging Science, $3(1): 1-5$.

https://doi.org/10.4103/2156$\underline{7514.122325}$

25. Rao KRI, Priya NS, Rao K, Ashwin DP. 2016, Brown tumor of mandible in association with primary hyperparathyroidism, Indian Journal of Oral Science, 7(1):54. https://doi.org/10.4103/0976$\underline{6944.176385}$

26. Shindo M, Lee JA, Lubitz CC, McCoy KL, Orloff LA, Tufano RP, et al, 2016, The changing landscape of primary, secondary, and tertiary 
hyperparathyroidism: Highlights from the American College of Surgeons Panel, "what's new for the surgeon caring for patients with hyperparathyroidism.", $J$ Am Coll Surg, 222(6):1240-1250. https://doi.org/10.1016/j.jamcollsurg.2 $\underline{016.02 .024}$

27. Pechalova PF, Poriazova EG. 2013, Brown tumor at the jaw in patients with secondary hyperparathyroidism due to chronic renal failure, Acta Medica, 56(2):83-86.

https://doi.org/10.14712/18059694.20 $\underline{14.29}$

28. Pati AR, Mubeen, Vijayalakshmi KR, Singh C. 2014, Diagnosis and clinicoradiological presentation in an aggressive maxillary brown tumour, Journal of Clinica; Diagnostic and Research, 8(5):13-15. https://doi.org/10.7860/JCDR/2014/75 $\underline{11.4358}$

29. Verma $P$, Verma $K G$, Verma $D$, Patwardhan N. 2014, Craniofacial brown tumor as a result of secondary hyperparathyroidism in chronic renal disease patient: A rare entity, Journal of Oral and Maxillofacial Pathology, 18(2):267-270.

https://doi.org/10.4103/0973029X.140779

30. Gedik GK, Ata O, Karabagli P, Sari O. 2014, Differential diagnosis between secondary and tertiary hyperparathyroidism in a case of a giant-cell and brown tumor containing mass, Journal of Nuclear Medicine, 17(3):214-217.

https://doi.org/10.1967/s00244991014 $\underline{7}$

31. Can Ö, Boynueğri B, Gökçe AM, Özdemir E, Ferhatoğlu F, Canbakan $\mathrm{M}$, et al. Brown Tumors: A Case Report and Review of the Literature, Case Reports Nephrol Dial. 2016;6(1):46-52. https://doi.org/10.1159/000444703
32. Masthan KMK, Anitha N, Krupaa J, Manikkam S. Ameloblastoma., Journal of Pharmatology Bioallied Science, 2015; 7(5): 167-170. https://doi.org/10.4103/0975$\underline{7406.155891}$ 